\title{
Work zone traffic management in rehabilitation of $\mathrm{M}-2$
}

\section{Muhammad Adeel 1(D, Muhammad Bilal Khurshid 1, Malik Kamran Shakir 2 (D)}

\author{
${ }^{1}$ Military College of Engineering (MCE), National University of Sciences and Technology, \\ Risalpur Cantonment, Pakistan \\ Department of Transportation Engineering \\ 2Institute of Civil Engineering (NICE), School of Civil and Environmental Engineering (SCEE), \\ National University of Sciences and Technology, Islamabad, Pakistan
}

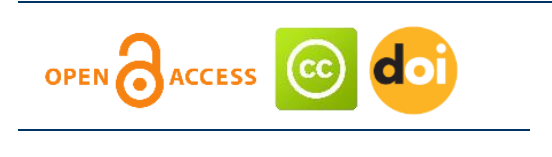

\section{Article history:}

Received: December 23, 2017

1st Revision: February 7, 2018

Accepted: March 10, 2018

\section{DOI:}

10.14254/jsdtl.2018.3-3.8
Abstract: Pakistan has a population of over 199 million and total road network of approximately 264,400 kilometers that serve about 16.2 million vehicles of all types. According to WHO estimates, there were approximately 30,000 annual Road Crash Fatalities (RCF) in Pakistan in year 2010. Work zone crashes account for significant proportion of all traffic crashes in Pakistan due to higher crash rate as compared to other parts of the highway network. Highway work zone is referred to road area where highway construction, maintenance or activity related to utility maintenance takes place. Workers in highway work zone are exposed to a variety of hazards and face risk of injury and death from construction equipment as well as passing motor vehicles. Safety measures and better understanding of risks involved while moving through the work zone have significant effects on the overall safety climate at work zones. Mismanaged work zone traffic increases the travel time delays, safety issues, vehicle operating costs (VOC) and other associated costs. Performance measures for the work zone traffic management includes user costs (travel time delay, crash cost, VOC), incident response and clearance time, queue length and community complaint. Different work Zone Traffic Management methodologies are being practiced worldwide and extensive research has been carried out at international level on country specific highway work zone safety but in Pakistan very few studies have been carried out on highway work zones. This research aims to critically analyze the impacts of the different Work Zone Traffic Management methods and recommend the best option for Expressways / Motorways in Pakistan. For the purpose of research, the author has selected a section of Motorway (M-2). Two different work zone traffic management methods are being followed in rehabilitation of M-2 i.e. Parallel / Adjacent Method and Median Cross-Over Method. Performance measures selected for purpose of analysis are

Corresponding author: Muhammad Adeel

E-mail: adeel102eb@gmail.com 
Travel Time Delay, Crash Cost (Safety) and VOC and data collected on section of M-2. After critical analysis, it is concluded that Parallel/ Adjacent Method results in lesser Travel Time delay and lesser VOC due to higher operating speeds and thus has higher savings, whereas Median Cross over Methods yield more Crash Cost savings. Keeping in view the driving habits / skills, poor maintenance of vehicles in Pakistan and risk of fatal accidents involved in parallel /adjacent method, median cross over method is preferred.

Keywords: work zone traffic management, highway work zone layout, rehabilitation, travel time savings, crash cost savings, vehicle operating cost savings.

\section{Introduction}

Nations around the globe continue to face the challenges posed by alarming increase in number of road crash fatalities and injuries. The Global Status Report on Road Safety - 2013, published by World Health Organization (WHO) states that about 1.24 million people die each year in road traffic crashes worldwide and approximately 20 to 50 million suffer from non-fatal injuries. The report was based on the road safety data collected from 182 countries. This accounted for almost $99 \%$ of the world's population. Unluckily, only 28 countries, which make up $7 \%$ of world population, have sufficient laws to address key road crash risk factors (Peden et al., 2004). There have been many efforts worldwide to quantify the economic effects of these fatalities and injuries. But their psychological impacts on social fibre of the society and individuals still need further research. Although, road traffic accidents have been among the major contributors of injuries in past, studies have shown that situation is getting worse. It is expected that by 2020 it will rank as high as 3rd cause of disease or injury worldwide (Peden et al., 2004). WHO data for 2002 shows that deaths caused by road traffic injuries were "20.2 per 100,000 populations in low / medium-income countries" which accounted for $90 \%$ of the total 1,183,492 road traffic related deaths in the world. Road traffic injuries put a huge burden on world economies. Road traffic injuries cost "approximately 1\% of the Gross National Product (GNP) in poor countries, 1.5\% in medium-income countries and 2\% in rich countries" (Jacobs, Aeron-Thomas, \& Astrop, 2000). The data collected from poor countries is not absolutely reliable, due to the lack of comprehensive data collection and incident recording procedures.

Pakistan has a large road network of 260,760 km of which 9,555 km are National Highways and $1,930 \mathrm{~km}$ are Motorways, serving approximately 11 million vehicles of all types. There has been overwhelming reliance on roads and highways in meeting transport demand with roads handling nearly 95 percent of all passenger and freight demand. A recent study shows that in Pakistan, approximately 30,000 people die every year because of road crashes (Ahmed, Khan, Khurshid, Khan, \& Waheed, 2016). As per WHO data, Pakistan has approximately 30,000 annual road crash fatalities (Organization, 2013). Road Crash Fatalities (RCF) and Road Crash Injuries (RCI) are expected to "increase by 65\% in next 10 years" unless there are "new efforts" to address the prevailing state of road safety around the world (Peden et al., 2004).

Highway work zone is the road area where highway construction, maintenance or activity related to utility maintenance take place (Turner, 1999). Workers in highway work zones are exposed to a variety of hazards and face risk of injury and death from construction equipment as well as passing motor vehicles. Regardless of task, most of the workers are exposed to dangerous conditions such as poor lighting, poor visibility, inclement weather, congested work areas, high volume traffic and over speeding vehicles. In USA alone, 87,606 crashes were caused by work zones in 2010 (FHWA, 2014). It is conceivable that work zone crash fatalities and injuries affect many families more devastatingly by the loss of working members of family and inflict a huge economic burden on the disabled persons and their families. A study carried was out on $196 \mathrm{~km}$ section of the Karachi-Hala Highway in Pakistan that utilized police reported crashes data from January 2006 to December 2008 to assess highway work zone crashes. The study concluded that work zone crashes accounted for as much as " $15.0 \%$ of all traffic 
crashes" (Bhatti, Razzak, Lagarde, \& Salmi, 2010). The present research paper study major highway work zone safety aspects in Pakistan. At present, not much work has been done to understand safety requirements of such work zones and there is a pressing need to study the subject in detail. Rehabilitation of any freeway / expressway requires unorthodox approach during execution phase. Work Zone Traffic Management holds an important place in any rehabilitation process due to the involvement of inbuilt travel time delays, safety cost and Vehicle Operating Cost (VOC).

In order to overcome safety problems at highway work zones in Pakistan, there is a need to develop a clear understanding of extent of the problem. This is only possible if the existing practices / methods of highway work zone traffic management are studied in detail and compared with respect to advantages/disadvantages of each and with respect to selected performance measures. Therefore, the objectives set forth for the present research were to synthesize the international and national literature on highway work zone safety to understand Pakistan specific issues. Synthesize the state of the art safety practices at highway work zone. Collection of highway work zone data from selected section of motorway (M-2). Comparison of different methods of highway work zone traffic management being practiced on M-2. Finally, selection of the most appropriate method for Pakistan highways.

\section{Literature review}

Literature review revealed that although some significant research efforts have been made by Pakistani researchers in the field of worker and work zone safety, but not much work has been done specifically related to highway work zone safety.

A study carried out detailed analyses of 29 reported highway work zone accidents cases across USA emphasized on adoption of simple measures like wearing of high visibility safety apparel, working in non-peak hours, use of flaggers and flashers to improve overall safety environment at work zones (Pratt, Fosbroke, \& Marsh, 2001).

Chen and Tarko in their research study attempted to model the safety of highway work zones using data from 72 work zones in USA. The study observed that crash frequency is proportional to length of work zone at decreasing rate. Also wider work zone right of way reduces the crash frequency. The study found that presence of detour sign served to reduce crashes in work zone (Chen \& Tarko, 2014).

A research carried out to study the work zones with specific reference to accommodating pedestrian, found that a large number of work zones did not pay any attention to pedestrian requirements (Morelli, Brogan, \& Hall, 2006). The researchers witnessed pedestrians in every work zone but none of them addressed the pedestrian accommodation perfectly. The study also highlighted the presence of a good number of unnecessary equipment at site which created additional hazards. Highway work zone presents a complex situation where hasty action to ensure safety may itself put safety of other workers or road users at risk.

In USA, during 1995-2002, 844 highway workers were killed at road construction work zones (Pegula, 2004). In 1999, 872 people were killed due to vehicle crashes into the work zone. This number rose to 1028 in 2003 (Li \& Bai, 2009). Working at highway work zone at night-time has a risk level as high as five times as compared to working at daytime (Arditi, Lee, \& Polat, 2007). In 2006, U.S. National Highway Safety Administration recorded more than 1000 fatal work zone (Morgan, Duley, \& Hancock, 2010). Another study shows that longer work zone duration increases the crash frequency at work zone (Khattak, Khattak, \& Council, 2002). Higher risk level suggests much extensive study of the safety issues at highway work zones, both for day and night work. Also there is a need for much elaborate measures for safety of highway workers and travellers.

Reliable crash data required for study of effectiveness of safety measures at work zones is not readily available in Pakistan. There is no formal organization responsible for collecting such for research purposes. OSHA in USA, HSE in UK, Safe Work Australia, EU-OSHA in European Countries etc. are some of the organizations which carry out research along with ensuring safety at work sites in their respective countries. Usefulness of MUTCD in making work zone safer has already been highlighted. This research utilizes the same for the evaluation of safety conditions at Pakistani work zones. 


\section{Research framework and methodology}

Figure 1. Research framework

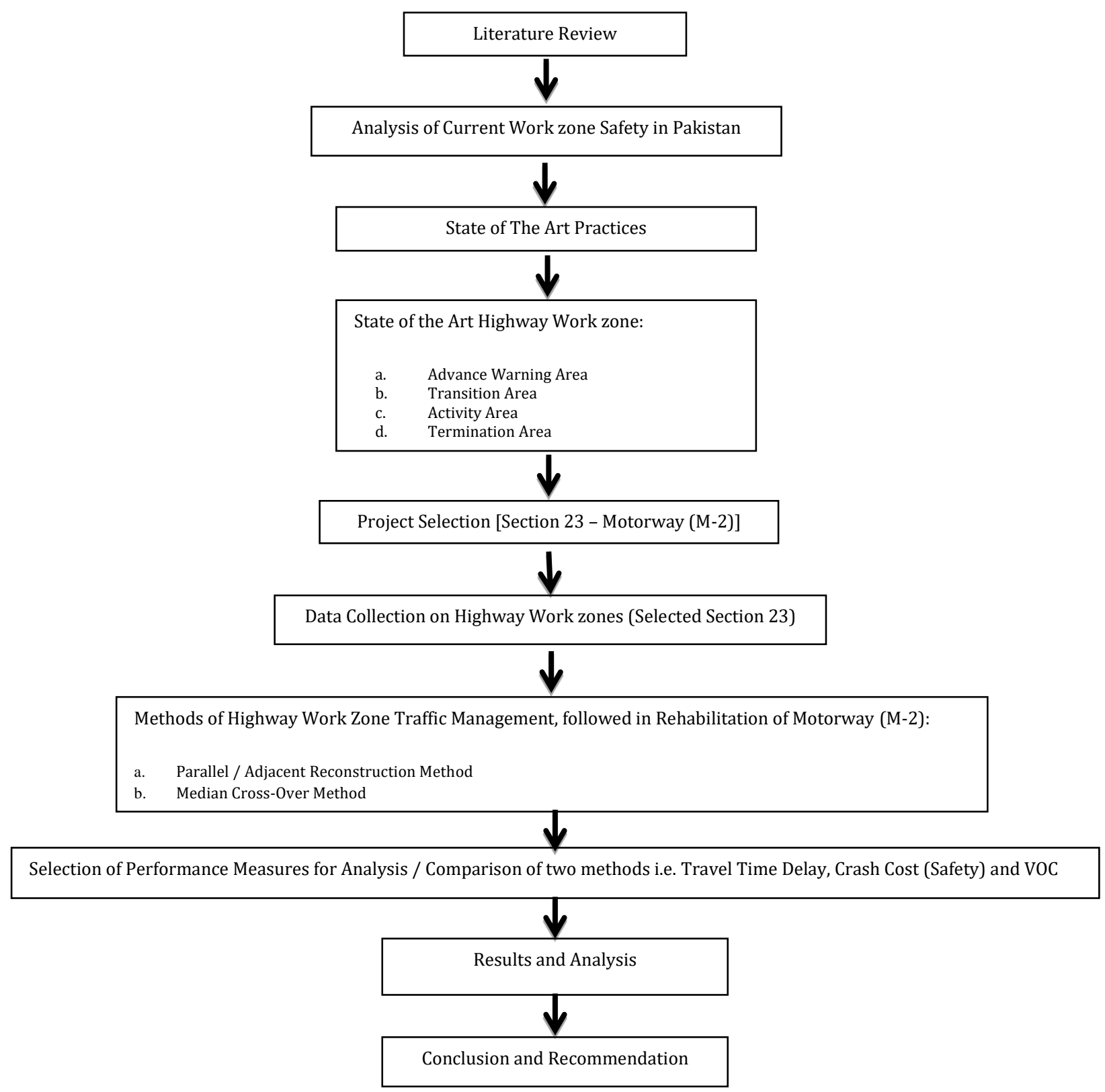

\section{State of the art highway work zone}

The first requirement for the assessment of any highway work zone is the identification of state of the art highway work zone to be used as bench mark, as mentioned in Fig. 1. There is no standard size for a highway work zone. Its size varies from situation to situation. It can be as small as few hundred feet and as long as several hundred meters. Thus exact size of work zone or any of its components cannot be given. Secondly the components of a work zone are not separate entities. Each component is linked with and merges with the next component. There are no physical boundaries of components and at the most a warning sign can specify end of one component and start of the next.

\section{Components of highway work zone}

For ease of understanding, a highway work zone can be divided into four components (U. FHWA, 2010): 
Advance warning area

Advance Warning Area (AWA) is the section of highway before the actual start of highway work area, where road users are warned about the upcoming hazards (U. FHWA, 2010). The purpose of AWA is to prepare the road user about the subsequent work zone conditions. An AWA may consist of a single sign or as series of signs but normally it consists of three signs that advise, warn and instruct the road user about the upcoming work zone (Hill, 2003).

Transition area

Transition Area is portion of highway that directs the road users out of their normal path. Transition Area serves to shift the traffic from hazardous lane to safer lane. Transition area must provide a predictable transition for the driver. A safe and predictable transition area serves as a useful and practicable measure to improve work zone safety.

Activity area

Activity area is part of the road where work actually takes place. The major components of activity area of a highway work zone are work space, traffic space and buffer space.

Termination area

Termination Area is the part of road that provides road users a clear path to return to their normal path from where they were diverted. It starts from the "downstream end of the activity area" and ends at the "last TTC device" at the downstream end of work zone.

\section{Project selection and collection of data}

Data was collected from a traffic study conducted in 2014 by a consultant firm ACC (Private) Limited on motorway (M-2), which was carried out before the start of rehabilitation of Motorway (M2). In that study, M-2 was divided into 24 different sections for purpose of data collection of Annual Average Daily Traffic (AADT). Section 23 was selected for the purpose of our research / analysis which start at Thokar Niaz Baig and finishes at Babu Sabu and consist of 5.6 miles (9 kms) in length and 3 lanes each side. Data recorded on Section 23 (Thokar Niaz Baig - Babu Sabu) is given in Tab. 1.

\section{Table 1. Data collected on Section 23 M-2 (Thokar Niaz Baig - Babu Sabu)}

\begin{tabular}{|c|c|c|}
\hline S/No & Nomenclature & Data \\
\hline 1 & Total AADT & $35,228 \mathrm{veh} /$ day \\
\hline 2 & No. of Cars & 22,595 veh /day \\
\hline 3 & No. of Trucks & 7,981 veh /day \\
\hline \multicolumn{3}{|c|}{ Operating Speeds on M-2 } \\
\hline 4 & Cars & $75 \mathrm{mph}$ \\
\hline 5 & Buses & $60 \mathrm{mph}$ \\
\hline 6 & Trucks & $50 \mathrm{mph}$ \\
\hline 7 & Operating Speeds (Parallel/Adjacent Method) & $50 \mathrm{mph}(80 \mathrm{kmph})$ \\
\hline 8 & Operating Speeds (Median Cross Over Method) & $37 \mathrm{mph}(60 \mathrm{kmph})$ \\
\hline \multicolumn{3}{|c|}{ Occupancy / Vehicle (Assumed) } \\
\hline 9 & Trucks & 1 \\
\hline 10 & Cars & 1.2 \\
\hline 11 & Buses & 40 \\
\hline \multicolumn{3}{|c|}{ Travel Time Costs (2015 constant PKR) } \\
\hline 12 & Cars & Rs. 282 / hr* \\
\hline 13 & Truck / Bus & Rs. $208 / \mathrm{hr}^{*}$ \\
\hline
\end{tabular}

\section{Methods followed in rehabilitation of $\mathbf{M - 2}$}

Two methods are being employed for highway work zone traffic management during rehabilitation of motorway (M-2):

Parallel / adjacent method

This method involves a variety of lane construction and lane closure sequences. In Phase 1, existing shoulders are widened with the fast lane reconstruction. In this phase, shoulder and slow lane will be closed and traffic will pass through middle and fast lane. In Phase 2, traffic is shifted to shoulders 
and outer lane while middle \& fast lane are closed for reconstruction. After completion, traffic returns to the original lanes. Speed is reduced by minimum $20 \mathrm{~km} / \mathrm{hr}$ from existing speed limits. Advantage of this method is that traffic is not required to cross over the median and does not operate in a two-way operation. Whereas disadvantages are that this method provides more constrained work area. Work crews are closer to moving traffic and access to the construction zone involves entry and exit from the travel lanes. Three-lane facility is reduced to two lanes to keep the two through lanes on the same side of the construction zone.

Median cross-over method

This method involves reconstruction of existing shoulders prior to the initiation of construction. Phase 1 consist of reconstruction of shoulders to allow one side of the roadway to accommodate four lanes. In Phase 2, all traffic is shifted to four available lanes on one side of the roadway. In Phase 3, construction of one side of 3 lanes and the shoulder takes place at the same time. Finally in Phase 4, traffic is shifted to the newly constructed side of the roadway.

\section{Research results and discussion}

Travel-time saving is the principle economic benefit assigned specially to urban transportation project. Other benefits, like reduced VOC and increase safety are also monetized. Travel time savings capture $80 \%$ of the quantified benefits for transportation Cost Benefit Analyses (CBA) in the United Kingdom.

\section{Travel time saving}

The overall goal of travel time impacts involves the estimation of travel time amounts, unit travel time value and the overall saving due to travel time delay cost as mentioned in Tab. 2 and Tab. 3 .

\section{Table 2. Travel Time Difference between Parallel and Median Cross-Over Method}

\begin{tabular}{ccccccc}
\hline S/No & Mode & $\begin{array}{c}\text { TT (Parallel } \\
\text { Method) } \\
\text { (Mins) }\end{array}$ & $\begin{array}{c}\text { TT (Median } \\
\text { Cross Over) } \\
\text { (Mins) }\end{array}$ & $\begin{array}{c}\text { TT Difference } \\
\text { (Mins) }\end{array}$ & $\begin{array}{c}\text { Rate / hr } \\
\text { (PKR) }\end{array}$ & $\begin{array}{c}\text { Vehicle } \\
\text { Occupancy }\end{array}$ \\
\hline 1 & Car & 6.72 & 7.72 & 1.00 & 282 & 1.2 \\
2 & Trucks & 6.72 & 7.72 & 1.00 & 208 & 1 \\
3 & Buses & 6.72 & 7.72 & 1.00 & 208 & 40 \\
\hline
\end{tabular}

\section{Table 3. Travel Time Benefit (Saving)}

\begin{tabular}{ccc}
\hline S/No & Vehicle & Travel Time Benefit (Parallel Method) (PKR)* \\
\hline 1 & Cars & $1,27,436$ \\
2 & Trucks & 27,667 \\
3 & Buses & $6,45,077$ \\
& Total Benefit per Day & $8,00,180$ \\
& Total Travel Time Benefit Per Annum & 292 M or 0.292 Billion PKR
\end{tabular}

*Travel Time Benefit $=$ (No. of vehicles $\mathrm{x}$ Occupancy) $\mathrm{x}$ (Difference of time between two methods (min) / 60) x Rate

\section{Safety saving}

Highway Safety Engineering is a branch of Traffic Engineering which deals with the study of reduction of the frequency as well as severity of crashes as mentioned in Tab. 4, Tab. 5 and Tab. 6 respectively. 
Table 4. Unit crash cost in year 2015 (2015 Constant PKR)

\begin{tabular}{|c|c|c|}
\hline S/No & Nomenclature & Data \\
\hline 1 & Per Capita Income of Pakistan (2015) & $\$ 1421$ \\
\hline 2 & Fatal Crash (70 times GDP per Capita) & $\begin{array}{c}\$ 99,500 \text { or Rs. } 10 \text { Million PKR } \\
\text { (Approx) }\end{array}$ \\
\hline 3 & Non-Fatal Crash (18 times GDP per Capita) & $\begin{array}{c}\$ 25,000 \text { or Rs. } 2.5 \text { Million PKR } \\
\text { (Approx) }\end{array}$ \\
\hline
\end{tabular}

Property Damage Only (PDO)

50,000 PKR (Assumed)

Source: Study - True Cost of Road Crashes (IRAP - International Road Assessment Program)

\section{Table 5. Number of Crashes Occurred in each Method}

\begin{tabular}{|c|c|c|c|c|c|c|}
\hline \multirow{2}{*}{$\begin{array}{l}\text { Work Zone } \\
\text { Traffic } \\
\text { Management } \\
\text { Method }\end{array}$} & \multicolumn{3}{|c|}{$\begin{array}{c}\text { Crashes } \\
\text { (Jan-Feb 2015) }\end{array}$} & \multicolumn{3}{|c|}{ Cost (Million PKR) } \\
\hline & Fatal & Non-Fatal & PDO & Fatal & Non-Fatal & PDO \\
\hline $\begin{array}{l}\text { Parallel/ } \\
\text { Adjacent }\end{array}$ & 3 & 8 & 11 & 10 & 2.5 & 0.05 \\
\hline $\begin{array}{l}\text { Median Cross- } \\
\text { Over }\end{array}$ & 1 & 6 & 14 & 10 & 2.5 & 0.05 \\
\hline
\end{tabular}

\begin{tabular}{|c|c|c|c|c|c|}
\hline \multirow{2}{*}{$\begin{array}{l}\text { Work Zone } \\
\text { Traffic } \\
\text { Management } \\
\text { Method }\end{array}$} & \multicolumn{3}{|c|}{ Cost (Million PKR) } & \multirow{2}{*}{$\begin{array}{c}\text { Total Cost } \\
\text { (Million PKR) } \\
\text { (Jan- } \\
\text { Feb 15) }\end{array}$} & \multirow{2}{*}{$\begin{array}{l}\text { Annual Crash Cost } \\
\text { Saving (Million PKR) }\end{array}$} \\
\hline & Fatal & Non-Fatal & PDO & & \\
\hline $\begin{array}{l}\text { Parallel/ } \\
\text { Adjacent }\end{array}$ & 30 & 20 & 0.55 & 50.55 & $\begin{array}{l}\text { Crash Cost Saving in } \\
\text { Median Cross Over } \\
\text { Method: }\end{array}$ \\
\hline $\begin{array}{l}\text { Median Cross } \\
\text { Over }\end{array}$ & 10 & 15 & 0.7 & 25.7 & $\begin{array}{l}152.1 \mathrm{M}(2015 \\
\text { Constant PKR) }\end{array}$ \\
\hline
\end{tabular}

\section{Vehicle Operating Cost (VOC) saving}

Vehicle operating cost (VOC) is a significant portion of highway transportation costs. Calculations are shown in Tab. 7, Tab. 8 and Tab. 9 respectively.

\begin{tabular}{|c|c|c|c|c|c|c|c|}
\hline Method & & $\begin{array}{l}\text { Type of } \\
\text { Vehicle }\end{array}$ & AADT & $\begin{array}{l}\text { Section } \\
\text { Length } \\
\text { (Miles) }\end{array}$ & $\begin{array}{l}\text { VMT / } \\
\text { Day }\end{array}$ & $\begin{array}{c}\text { Operating } \\
\text { Speed } \\
\text { (mph) }\end{array}$ & $\begin{array}{c}\text { Unit VOC } \\
\text { (PKR / Mile) }\end{array}$ \\
\hline \multirow{3}{*}{\multicolumn{2}{|c|}{$\begin{array}{l}\text { Parallel/ } \\
\text { Adjacent } \\
\text { Method }\end{array}$}} & Cars & 22,595 & 5.6 & 12,6532 & 50 & 25.71 \\
\hline & & Trucks & 7,981 & 5.6 & 44,694 & 50 & 33.07 \\
\hline & & Buses & 4,652 & 5.6 & 26,051 & 50 & 33.07 \\
\hline \multirow{3}{*}{$\begin{array}{l}\text { Median } \\
\text { Over }\end{array}$} & \multirow{3}{*}{ Cross } & Cars & 22,595 & 5.6 & 12,6532 & 43.5 & 26.03 \\
\hline & & Trucks & 7,981 & 5.6 & 44,694 & 43.5 & 34.22 \\
\hline & & Buses & 4,652 & 5.6 & 26,051 & 43.5 & 34.22 \\
\hline
\end{tabular}




\begin{tabular}{|c|c|c|c|c|}
\hline Method & $\begin{array}{l}\text { Type of } \\
\text { Vehicle }\end{array}$ & $\begin{array}{l}\text { Total } \\
\text { (Unit V0C } \\
\text { Saving) }\end{array}$ & $\begin{array}{c}\text { VOC Saving / } \\
\text { Day }\end{array}$ & $\begin{array}{c}\text { Total VOC Saving (Million } \\
\text { PKR) } \\
\text { VOC Saving / Day x } 365\end{array}$ \\
\hline \multirow{3}{*}{$\begin{array}{l}\text { Parallel/ } \\
\text { Adjacent Method }\end{array}$} & Cars & 0.32 & 40456 & \multirow{3}{*}{$44.4 \mathrm{M}$} \\
\hline & Trucks & 1.15 & 51318 & \\
\hline & Buses & 1.15 & 29912 & \\
\hline
\end{tabular}

Table 9. Net benefit (Savings)

\begin{tabular}{|c|c|c|c|}
\hline Method & Category (Savings) & $\begin{array}{c}\text { Saving } \\
\text { (Million PKR) }\end{array}$ & $\begin{array}{l}\text { Net Saving } \\
\text { (Million PKR }\end{array}$ \\
\hline \multirow{3}{*}{ Parallel / Adjacent } & Travel Time & 292 & \multirow{6}{*}{$\begin{array}{l}\text { Parallel Method w.r.t } \\
\text { Median Cross-Over } \\
\text { Method: } \\
184.3 \mathrm{M}\end{array}$} \\
\hline & Safety & - & \\
\hline & VOC & 44.4 & \\
\hline \multirow{3}{*}{ Median Cross Over } & Travel Time & - & \\
\hline & Safety & 152.1 & \\
\hline & VOC & - & \\
\hline
\end{tabular}

\section{Conclusion}

In this research an attempt has been made to increase understanding of current level of safety conditions at highway work zones in Pakistan. The MUTCD provides an easy to follow and well tested design for highway work zones. Such a design ensures safe and efficient flow of traffic through work zone. The analysis of the results revealed that Parallel/Adjacent Method results in lesser Travel Time delay and lesser VOC due to higher operating speeds and thus have higher savings. Whereas, Median Cross-Over Methods yield Safety Savings. However, impact of the factors like interference of construction machinery/ vehicles with the through traffic in parallel/adjacent method could not be ascertain for the obvious reasons of being incalculable.

\section{Recommendations and direction for future research}

Apropos of research findings it is recommended that: MUTCD

(1) Highway work zones must be established according to well-tested recommendations of

(2) From pure economic / monetary point of view, parallel / adjacent method of Work Zone Traffic Management is recommended

(3) However, keeping in view the driving habits / skills, poor maintenance of vehicles in Pakistan and risk of fatal accidents involved in parallel / adjacent method, median cross over method should be preferred

(4) If parallel method is adopted due to some unavoidable circumstances, extra care for the safety of the working crew and machinery must be taken through a deliberate layout and enforcement of speed limit

(5) Sufficient funds must be allocated in project estimates for proper temporary traffic control measures

(6) In this regards a comprehensive study is required to be carried out to analyse safety measures at highway work zones viz-a-viz contractual and legal bindings 


\section{Acknowledgement}

The contents of this paper reflect the views of the writers who are responsible for the facts and the accuracy of the data presented herein and do not necessarily reflect the official views or policies of the government departments, nor do the contents constitute a standard, specification, or regulation.

\section{Appendix A. Supplementary material}

Supplementary data associated with this article can be found, in the online version, at https://jsdtl.sciview.net

\section{Funding}

The authors received no direct funding for this research.

\section{Citation information}

Adeel, M., Khurshid, M. B., \& Shakir, M. K. (2018). Work zone traffic management in rehabilitation of M-2. Journal of Sustainable Development of Transport and Logistics, 3(3), 99-108. doi:10.14254/jsdtl.2018.3-3.8.

\section{References}

Ahmed, A., Khan, B. A., Khurshid, M. B., Khan, M. B., \& Waheed, A. (2016). Estimating national road crash fatalities using aggregate data. International journal of injury control and safety promotion, 23(3), 249-254.

Arditi, D., Lee, D.-E., \& Polat, G. (2007). Fatal accidents in nighttime vs. daytime highway construction work zones. Journal of Safety Research, 38(4), 399-405.

Bhatti, J. A., Razzak, J. A., Lagarde, E., \& Salmi, L. R. (2010). Burden and factors associated with highway work-zone crashes, on a section of the Karachi-Hala Road, Pakistan. Injury prevention, ip. 2010.027532.

Chen, E., \& Tarko, A. P. (2014). Modeling safety of highway work zones with random parameters and random effects models. Analytic methods in accident research, 1, 86-95.

Economic Survey of Pakistan (ESP). (2017). Retrieved from http://www.finance.gov.pk/ and http://www.finance.gov.pk/survey_1617.html.

FHWA. (2014). Work zone Injuries and Fatalities. Work zone Mobility and Safety Program.

FHWA, U. (2010). Manual on uniform traffic control devices (2009). Baton Rouge: Claitor's Law Books and Publishing, 137-179.

Hill, D. C. (2003). Construction safety management and engineering: Amer Society of Safety Engineers.

Jacobs, G., Aeron-Thomas, A., \& Astrop, A. (2000). Estimating global road fatalities.

Khattak, A. J., Khattak, A. J., \& Council, F. M. (2002). Effects of work zone presence on injury and non-injury crashes. Accident Analysis \& Prevention, 34(1), 19-29.

Li, Y., \& Bai, Y. (2009). Effectiveness of temporary traffic control measures in highway work zones. Safety science, 47(3), 453-458.

Morelli, C. J., Brogan, J. D., \& Hall, J. W. (2006). Accommodating Pedestrians in Work Zones. Paper presented at the TRB 2006 Annual Meeting CDROM.

Morgan, J., Duley, A., \& Hancock, P. (2010). Driver responses to differing urban work zone configurations. Accident Analysis \& Prevention, 42(3), 978-985.

Organization, W. H. (2013). Global status report on road safety 2013: supporting a decade of action: summary.

Peden, M., Scurfield, R., Sleet, D., Mohan, D., Hyder, A. A., Jarawan, E., \& Mathers, C. D. (2004). World report on road traffic injury prevention: World Health Organization Geneva. 
Pegula, S. (2004). Fatal occupational injuries at road construction sites. Monthly Lab. Rev., 127, 43.

Pratt, S. G., Fosbroke, D. E., \& Marsh, S. M. (2001). Building safer highway work zones; measures to prevent worker injuries from vehicles and equipment.

Turner, J. D. (1999). What's a Work Zone?. Public roads, 62(6).

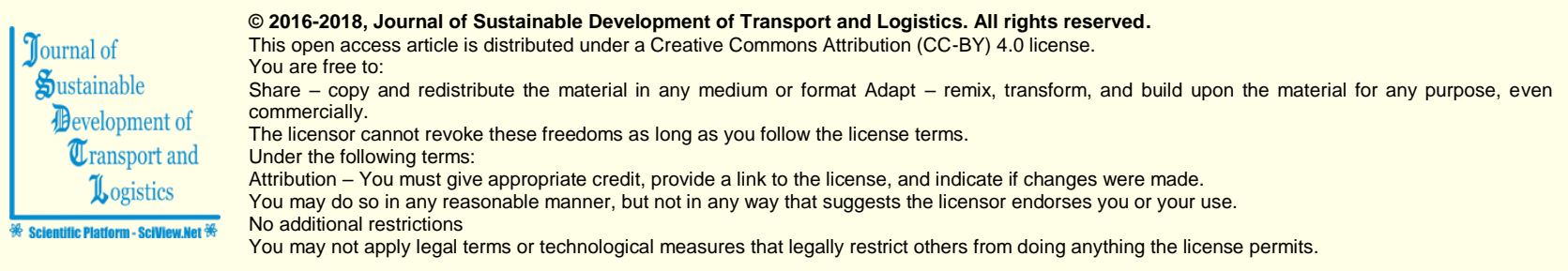

Journal of Sustainable Development of Transport and Logistics (ISSN: 2520-2979) is published by Scientific Publishing House "CSR", Poland, EU and Scientific Publishing House "SciView", Poland, EU

Publishing with JSDTL ensures:

- Immediate, universal access to your article on publication

- High visibility and discoverability via the JSDTL website

- Rapid publication

- Guaranteed legacy preservation of your article

- Guaranteed legacy preservation of your article

Submit your manuscript to a JSDTL at https://jsdtl.sciview.net/ or submit.jsdt|@sciview.net 